\title{
Bioaccumulation of heavy metals by the flora and benthic macrofauna of the Bouregreg estuary wetland
}

\author{
M. Khamar, E. Cherkaoui et A. Nounah \\ Laboratory of Civil Engineering and Environment (LGCE), \\ Higher School of Technology, SALE, Mohammed V University in Rabat. \\ e-mail:m_khamar@yahoo.fr
}

\begin{abstract}
Estuarine systems account for a high proportion of wetlands in Morocco due to the development of the river system. These estuarine and coastal Moroccan environments are as rich in fauna and flora as their European equivalents and present much originality. However, these coastal areas are generally highly urbanized and industrialized, and therefore subject to domestic and industrial discharges. The Bouregreg Estuary represents a good example of this situation, in view of this pollution (organic, chemical and biological) and the absence of fresh water supply upstream of the estuary after the dam was built, is increasingly unable of restoring the equilibrium of this ecosystem. This tide can instead ensure the polluting discharge downstream or upstream. Metallic contamination affects the different compartments of the estuarine ecosystem (sediment, water) and benthic species (fauna and flora). The objective of this study is to assess the accumulation and bioaccumulation of five heavy metals $(\mathrm{Cu}, \mathrm{Fe}, \mathrm{Zn}, \mathrm{Cr}$ and $\mathrm{Pb})$ at the sediment level of two dominant plant species (Artiplex portulacoides and Sarcocornia fructicosa) and three species of benthic macrofauna (Scrobicularia plana, Venerupis decussata and Hediste diversicolor) from the wetland of this estuary. This work will enable us to clearly understand the nutritional relationships between plant, animal, water and sediment species. The results of the analysis revealed that bioaccumulation varies from one species to another and from one metal to another. Thus, the levels of Lead and Chromium at Sarcocornia fructicosa are higher than those found at Artiplex portulacoides. Nevertheless, the latter accumulates better the other metals: $\mathrm{Cu}, \mathrm{Zn}$ and Fe. While, the macrofauna shows a fairly large variation depending on the life style and sensitivity of species. Thus, Hediste diversicolor showed high levels of the various metals analyzed compared to Scrobicularia plana and Venerupis decussata.
\end{abstract}

Key words: Estuary of Bouregreg, Heavy metals, Bioaccumulation, flora, macrofauna, water, sediment

\section{INTRODUCTION}

The estuaries are environments of great ecological and economic importance. Urban and industrial pressure, as well as the development of estuaries, leads to an increase in their pollution [9]. On the Atlantic coast of Morocco, the estuary of Bouregreg is an edifying case of this situation. Indeed this estuary drains in its passage the polluted rejections of many industrial units and the untreated domestic rejections of some districts of the two agglomerations Rabat and Salé which do not cease developing in its surroundings.

Anthropogenic activities are the source of many pollutants disseminated in the environment, in particular heavy metals. The latter result either from discharges directly into ecosystems or from indirect flows such as industrial discharges, landfill leachate, agricultural runoff . The estuary of Bouregreg does not escape this scourge. Several studies have revealed the contamination of this estuary in these different compartments $([15,20])$. 
Among the main pollutants generated by industrial activities are heavy metals $(\mathrm{Cu}, \mathrm{Pb}, \mathrm{Cr}$, etc.) which formally pose particular problems of concern. Thus the presence of a fraction of heavy metals in the aquatic environment is reversibly associated with superficial sediments. These elements, by nature non-biodegradable, accumulate in the sediment and present a high toxicity to the fauna and flora of this ecosystem [14]. This bioaccumulation of toxic metals will cause neffffects in biological chains is one of the most pernicious effects of marine pollution.

The objective of this study is to assess the accumulation and bioaccumulation of these five heavy metals $(\mathrm{Cu}, \mathrm{Fe}$, $\mathrm{Zn}, \mathrm{Cr}$ and $\mathrm{Pb}$ ) in the sediment and two dominant plant species (Artiplex portulacoides and Sarcocornia fructicosa) And three animal species belong to the zoobenthic groups (Scrobicularia plana, Venerupis decussata and Hediste diversicolor) of the wetland of the downstream part of this Bouregreg estuary. This work will allow us to clearly identify the nutritional relationships between the living part (plant and animal species) on the one hand and their biotopes (water and sediment) on the other hand. In addition to the role of these benthic species as bioindicators of the aquatic ecosystem, this makes it possible to perceive their impacts on consumer health (man).

\section{MATERIALS AND METHODS}

The estuary of Bouregreg is located on the Moroccan Atlantic between the two cities Rabat and Salé at $34^{\circ}$ north and $6^{\circ} 50$ 'west. It has a length of $23 \mathrm{~km}$, limited upstream by the Sidi Mohammed Ben Abdellah dam and an average width of $150 \mathrm{~m}$ (Fig1). This estuarine ecosystem has several original features linked, on the one hand, to its disturbed state by anthropogenic action (increase in urban effluents and reduction of terrigenous and freshwater effluents in the watershed) and, on the other hand, to its Natural situation, isolated on a long straight coast, beaten by the great swells of the Atlantic. Indeed, this estuary has a natural vegetation cover composed of indigenous species specific to wetlands and terrestrial (eucalyptus, ..). After the development of the Bourgegreg estuary with the closure and rehabilitation of the Oulja landfill, the construction of the Bettana collector and the construction of the banks for the construction of the New Hassan II bridge and the My bridge. Youssef in addition to the closuture of the Akreuch dump. The wetland has suffered considerable degradation by limiting its area (construction of the marina on the right bank of the river and the development of the banks). Although these species have adapted very well to these changes. This leaves a greater value for diversity and species richness. In addition to this wetland estuary provides a refuge for many species of fish, birds, amphibians, mammals and reptiles and in addition a fairly high diversity of benthic macrofauna [5].

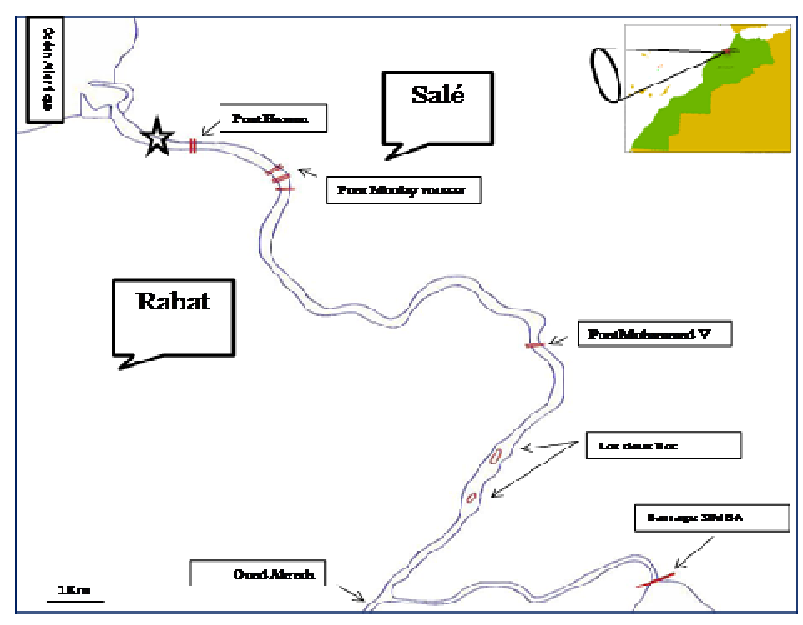

Fig.1: Location of the study area ( $\star$ ).

The study of the impact of discharges of wastewater and waste at the estuary level is approached by the accumulation of five heavy metals: $\mathrm{Cu}, \mathrm{Zn}, \mathrm{Pb}, \mathrm{Cr}, \mathrm{Fe}$ in two plant species (Artiplex portulacoides and Sarcocornia fructicosa) And three animal species belong to the zoobenthic groups (Scrobicularia plana, Venerupis decussata and Hediste diversicolor) of the Bouregreg estuary. This choice has been dictated by the fact that these metals are commonly used in industrial units and also because they are characterized by high toxicity to humans and aquatic organisms.

To carry out this work, sampling of plant species was done by hand. Once in the laboratory, we dry the harvested plants. This is an indispensable operation for the determination of species. We introduce the plants carefully, flat in a newspaper that will have to be changed every day. The determination is made at the Rabat Institute of Science in the Botanical Laboratory. For the analysis of heavy metals, both species are rinsed with tap water and then with distilled water. They are dried at $60^{\circ}$ C. to constant weight and then crushed.

For the macrofauna, sampling was carried out in the slikkes at low tide by the flat drill at a depth of 15 to 20 $\mathrm{cm}$ and then sieved on a sieve with a diameter of $1 \mathrm{~mm}$ of opening of the mesh. The sampled species (Scrobicularia plana, Venerupis decussata and Hediste diversicolor) are washed under tap water and then rinsed with distilled water. The pulp of ten individuals of each species collected separately in boxes, dried in an oven at $60^{\circ} \mathrm{C}$ to constant weight. It is then finely ground. Water and sediments are taken from the same area of collection of animal and plant species. 
The five metals were assayed at the UATRS at the National Center for Scientific and Technical Research (CNRST).

\section{RESULTS AND INTERPRETATIONS}

\subsection{Water and Sediment}

According to the classification of Chassé \& Glémarec (1976), the sediments of the study area are dominated by fine sands $(74.745 \%)$ and pelites $(17.16 \%)$, the other coarse sand and gravel fractions do not exceed Not ??? the $10 \%$, coarse sand and gravel represent $4.75 \%$ and $3.15 \%$ respectively (Table 1 ).

Table 1: Formation of the sediment of the study area.

\begin{tabular}{|c|c|}
\hline The sedimentary fraction & The percentage \\
\hline Pelites $(<63 \mu \mathrm{m})$, & $17,165 \%$ \\
\hline Fine sand $(63-500 \mu \mathrm{m})$ & $74,745 \%$ \\
\hline Coarse sands $(>500 \mu \mathrm{m})$, & $4,575 \%$ \\
\hline gravels & $3,515 \%$ \\
\hline
\end{tabular}

The sediment of this area of the estuary is well classified with the Trask index (1.58). The median is $200 \mu \mathrm{m}$, which is justified by a fine characteristic [14]. On the other hand, the loss on fire revealed that the organic matter in the sediments oscillates between $3 \%$ and $3.5 \%$. Analysis of the five metallic elements $(\mathrm{Cr}, \mathrm{Cu}, \mathrm{Zn}, \mathrm{Pb}$ and $\mathrm{Fe}$ ) in the waters of the Bouregreg estuary showed that, with the exception of iron, concentrations of other elements $(\mathrm{Cr}, \mathrm{cu}, \mathrm{Zn}$ and $\mathrm{Pb}$ ) remain below the unit. The chromium remains below the limit of detection, whereas the iron constituting the soil is at a concentration of $0.8 \mathrm{~g}$ / 1. The comparison of its contents with the codex standards shows that Fe exceeds the norm by 0.48 times, and 0.05 times for $\mathrm{Cu}$, and 0.1 times for $\mathrm{Pb}$ (Table 2).

Table 2 : Heavy metal content in the waters, sediments of the study area of the Bouregreg estuary.

\begin{tabular}{|c|c|c|c|c|c|}
\hline Compartiment & $\mathbf{C r}$ & $\mathbf{C u}$ & $\mathbf{P b}$ & $\mathbf{Z n}$ & $\mathbf{F e}$ \\
\hline $\begin{array}{c}\text { Water of the estuary } \\
(\mathrm{mg} / \mathrm{l})\end{array}$ & $\begin{array}{c}<0,0 \\
4\end{array}$ & 0,02 & 0,715 & 0,01 & 800 \\
\hline CODEX Standards & & 0,400 & 0,100 & & $\begin{array}{c}1,50 \\
0\end{array}$ \\
\hline sediment (mg/kg) & 84,3 & 16,86 & 2 & 1 & 0 \\
\hline
\end{tabular}

While concentrations of these metals are appreciable in sediments. The concentration varies from metal to metal. The average tensides of metallic elements ranging from $16.86 \mathrm{mg} / \mathrm{kg}$ for copper to $146.12 \mathrm{mg} / \mathrm{kg}$ for lead and $59.01 \mathrm{mg} / \mathrm{kg}$. With the exception of iron with an average grade of $16,500 \mathrm{~g} / \mathrm{kg}$, this is related to the geological nature of the region (iron-rich land); Nevertheless, these elements $(\mathrm{Cr}, \mathrm{Cu}$ and $\mathrm{Pb})$, which are found in quantities less than one in water, show significant sediment concentrations. This highlights the importance of the sediment compartment of this estuarine ecosystem in the accumulation of these elements of the aquatic environment. Although the lead content in the Bouregreg estuary is comparable to that observed in the same estuary before the development project ([3], [21]) and lower than in the estuary of Loukkos and Oum Errbia [11] [18].

\subsection{The Macrofauna}

Aquatic environments are colonized by animal and plant populations, whose structure under normal conditions responds to a certain balance. The bioaccumulation of metallic elements is linked to the metabolism of the species to ensure its growth and maintains its ionic balance.

For the three species studied (Hediste diversicolor Scrobicularia plana and Venerupis decussata) the accumulation of different metallic elements from one species to another according to the element.

\section{Venerupis decussata:}

The association of $\mathrm{Fe}$ in Venerupis decussata is very high, followed by $\mathrm{Zn}, \mathrm{Pb}, \mathrm{Cu}$ and $\mathrm{Cr}$. However, it remains the weakest in comparison with the other two species (Hediste diversicolor, Scrobicularia plana). From the comparison of the heavy metal values at this level with the codex standards, we notice an increase of almost 1067 times for The $\mathrm{Fe}, 33$ times for $\mathrm{Cu}$ and 262 times for the $\mathrm{Pb}$. These high concentrations can be judged by the existence of industrial discharges near the estuary, and it can be said that this species is unfit for human consumption. (Fig. 2)

\section{Hediste diversicolor:}

The concentration of $\mathrm{Fe}$ in $\mathrm{H}$. diversitor is very high, followed by $\mathrm{Zn}, \mathrm{Pb}, \mathrm{Cu}$ and $\mathrm{Cr}$.

Based on the comparison of the values of heavy metals in this species with Codex standards, we note an increase of 2600 times for $\mathrm{Fe}, 332$ times for $\mathrm{Pb}$, and 55 times for $\mathrm{Cu}$. These high concentrations are not only due to the existence of industrial discharges near the estuary, but also to the nature of the species. It can be said that the species is not suitable for human consumption (Fig 2)

\section{Scrobicularia plana:}

The iron concentration in Scrobicularia plana is also very high, followed by $\mathrm{Zn}, \mathrm{Pb}, \mathrm{Cu}$, and $\mathrm{Cr}$. However, it remains weaker than that of Hediste diversicolor. When we compare these values with those of Codex, we notice 
an increase of 1800 times for $\mathrm{Fe}, 281$ times for $\mathrm{Pb}$ and 59 times for $\mathrm{Cu}$. With a $\mathrm{Zn}$ content which is the highest compared to the two other species. This species is also unsuitable for human consumption. (Fig. 2)

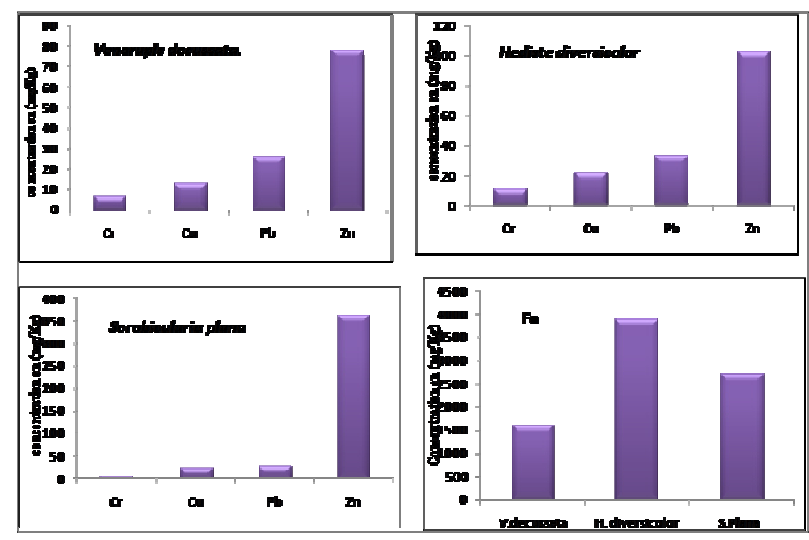

Figure 2: Variations of the $\mathrm{Zn}, \mathrm{Pb}, \mathrm{Cu}, \mathrm{Cr}$ and $\mathrm{Fe}$ contents in the benthic macrofauna Bouregreg estuary

The rate of bioaccumulation varies greatly from one species to another. It is also observed that the concentration of Fe within Hediste is much higher than that found in the other two species, with a multiplication factor of 2.44 with respect to the clam, and 1.44 with respect to Scrobicularia plana. The concentration of iron, a major element of the parent rock, remains very high in H. diversicolor $(3.9 \mathrm{~g} / \mathrm{kg})$. This accumulation in the three species results from the bioavailability of the metals, in parallel with the role that the physico-chemical parameters of the $\mathrm{pH}$, salinity and temperature may play in addition to the physiological processes specific to the species. However, Scrobicularia plana showed strong accumulations in $\mathrm{zn}$ with a multiplication factor of 4.61 with respect to the clam, and 3.55 with respect to Hediste diversicolor. This result remains comparable to that found in the same species by Kaimoussi et al.1998 [15], and remains less than that noted in Chamelea gallina at the mouth of the Oued Moulouya [1] (Fig. 2). While, for lead, chromium and copper, the three species show no significant differences in accumulation.

However, the levels of chromium and lead remain lower than those recorded in the sediments of the three species. While zinc is found at high concentrations in all three species compared to concentrations analyzed in sediment. Similarly for copper in S.plana and H. diversicolor (Table 3). This could be related to the mode of nutrition of these species. In fact, these molluscs are filtering species. While polychaetes are psamnivores (eat sand and assimilate nutrient particles), these polychaetes can consume highly degraded halophytic plants (either the animal prospects around its burrow without leaving it completely, or it emits a net of mucus trapping particles Out of his gallery).

Table 3: Comparison of heavy metal content in animal species and WHO standards and Codex standards.

\begin{tabular}{|c|c|c|c|c|c|}
\hline Compartiment & $\mathbf{C r}$ & $\mathbf{C u}$ & $\mathbf{P b}$ & $\mathbf{Z n}$ & $\mathbf{F e}$ \\
\hline V.decussata $(\mathrm{mg} / \mathrm{kg})$ & 6,55 & 13,1 & 26,21 & 78,62 & 1600 \\
\hline S.plana $(\mathrm{mg} / \mathrm{kg})$ & 6,47 & $\begin{array}{l}23,7 \\
4\end{array}$ & 28,05 & $\begin{array}{l}362,5 \\
5\end{array}$ & 2700 \\
\hline H. diversicolor $(\mathrm{mg} / \mathrm{kg})$ & $\begin{array}{l}11,0 \\
6\end{array}$ & $\begin{array}{l}22,1 \\
1\end{array}$ & 33,17 & $\begin{array}{l}102,2 \\
7\end{array}$ & 3900 \\
\hline Sediment (mg/kg) & 84,3 & $\begin{array}{l}16,8 \\
6\end{array}$ & $\begin{array}{l}146,1 \\
2\end{array}$ & 59,01 & $\begin{array}{l}1650 \\
0\end{array}$ \\
\hline S.marginatus $(\mathrm{mg} / \mathrm{kg})$ & 1.44 & 12.5 & 4.66 & 63.01 & 662.5 \\
\hline $\begin{array}{l}\text { M.galloprovincialis } \\
(\mathrm{mg} / \mathrm{kg})\end{array}$ & 1.93 & 12.4 & 8.31 & 232.7 & 416.7 \\
\hline Standards WOH 1982 & - & 10 & 5 & 100 & - \\
\hline Standards CODEX & & 0,40 & 0,100 & & 1,50 \\
\hline
\end{tabular}

The concentration of the metallic elements $(\mathrm{Cu}, \mathrm{Pb}$ and $\mathrm{Fe}$ ) for the three species exceeds the standards allowed by WHO 1982 with the exception of $\mathrm{Zn}$ in V. decussata [29], and those of Codex with reports in the order of 59,35 times (S. plana) and 32.75 (V.decussata) and 55 times for H.diversicolor for copper. This variation in concentrations may be related to the lifestyle of the three species. Indeed $V$. decussata life buried to a few centimeters (maximum $15 \mathrm{~cm}$ ) in the substrate to the infralittoral stage. It enjoys varied substrates of sand, small muddy gravel and mud, while Scrobicularia plana species of the mediolateral is present up to a few meters deep while Hediste diversicolor is a maple tree species that lives in a U-shaped gallery or Of $\mathrm{Y}$ in muddy or sandy muddy sediments. This habitat situation will influence their diets (water and sediment) and consequently the concentration of the different heavy metals. This is evident when comparing these concentrations with those found in M. galloprovincialis, which is fixed to the rocks of the mouth of the estuary of Bouregreg, and which replenishes only water, and shows concentrations much lower than those Recorded in our species (Table 3) [6].

\subsection{Plant species}

The Bouregreg Estuary revealed the presence of 14 species in 9 families, most of which are located in the wetland area of the marina. In this zone the family of CHENOBODIACEAE remains dominant by two species Artiplex portulacoides and Sarcocornia fructicos.) The presence of these species results from biotope that favors their development. Indeed, for Artiplex portulacoides is the typical plant of the highest areas of salt areas, out of 
reach of regular floods. However, it can withstand immersion for a short time; While Sarcocornia fructicosa prefers well drained, sandy and saline soils. It easily tolerates spray and drought. For good growth, it must be exposed to the sun, to the partial shade [12].

Analysis of the five metallic elements $(\mathrm{Cr}, \mathrm{Cu}, \mathrm{zn}, \mathrm{Pb}$ and $\mathrm{Fe})$ in the two plant species shows that: iron has two relatively high values in both species $(200 \mathrm{mg} / \mathrm{Kg}$ for Atiplex portulacoides and $300 \mathrm{mg} / \mathrm{Kg}$ For Sarcocornia fructicosa). For zinc and copper the highest values are present in Artiplex portulacoides. As regards chromium and lead, they are characterized by a significant decrease compared to other metals in both species, especially chromium. (Figure 3). The comparison between these two species shows that Artiplex portulacoides accumulates more copper, zinc, with contents of the order of 129.38 and $98.44 \mathrm{mg} / \mathrm{kg}$ respectively, while Sarcocornia fructicosa accumulates more chromium of lead and iron, with Values of $12.75 ; 35.05$ and $300 \mathrm{mg} /$ $\mathrm{kg}$ respectively. This deference of accumulation between the two species could be related to the physiology and morphology of each species and mainly their root system and the shape and leaf area.

These values are lower than those recorded in sewage irrigated bean $(\mathrm{Cu} 1.775 \mathrm{~g} / \mathrm{kg}$, Zn $1.4 \mathrm{~g} / \mathrm{kg}$ [12] and in the tomato stem $17.7 \mathrm{~g} / \mathrm{kg}$ of copper.17 However, the concentration Of $\mathrm{Zn}$ is less than that of lettuce $(194 \mathrm{mg} /$ kg). [19] However, the high concentrations of these two metals $(\mathrm{Cu}$ and $\mathrm{Zn})$ in addition to iron are due to the metabolic requirements of the plant. These elements are part of the composition of certain enzymes or serve as cofactors for the development of the plant [28].
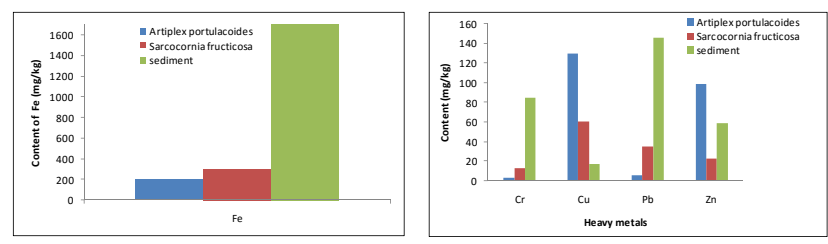

Fig.3: $\mathrm{Cr}, \mathrm{Cu}, \mathrm{Pb} \mathrm{Zn}$ and $\mathrm{Fe}$ content in both plant species

Although most of the heavy metals detected in water and sediments are found to accumulate in appreciable quantities in the different aerial parts (stem, leaf) of the two plant species (Table 4). Certainly the accumulation of metals by plants is linked to different mechanisms. Indeed, plants have a very extensive root system that they use to extract water and minerals from the soil necessary for their growth. During this extraction, they also absorb other compounds dissolved in the aqueous phase. These mechanisms are also used for toxic compounds in the environment such as heavy metals. The transfer of metal in contaminated soil to plants depends on its bioavailability and solubility and the $\mathrm{pH}$ of the biotope [25]. Elevated metal concentrations were observed in the tissues of the Brassicajuncea plant (for $\mathrm{Zn}, \mathrm{Cu}$ and $\mathrm{Pb}$ ), particularly in plant leaves in low pH $(2029 \mathrm{mg} / \mathrm{kg}, 71$ $\mathrm{mg} / \mathrm{kg}$ and $55 \mathrm{Mg} / \mathrm{kg}$, respectively) [8]. Other authors have linked the accumulation of heavy metals in plants to the concentration of these metals in the soil [27], plant genetics [10], soil physico-chemical $(\mathrm{pH}, \mathrm{Eh}$, organic matter, Amount of clay) ([24] - [16]).

Table 4: Heavy metal content in the waters, sediments and plants of the Bouregreg estuary wetland.

\begin{tabular}{|l|c|c|c|c|c|}
\hline \multicolumn{1}{|c|}{ Compartiment } & $\mathrm{Cr}$ & $\mathrm{Cu}$ & $\mathrm{Pb}$ & $\mathrm{Zn}$ & $\mathrm{Fe}$ \\
\hline V.decussata $(\mathrm{mg} / \mathrm{kg})$ & 6,55 & 13,1 & 26,21 & 78,62 & 1600 \\
\hline S.plana $(\mathrm{mg} / \mathrm{kg})$ & 6,47 & 23,7 & 28,05 & 362,5 & 2700 \\
\hline H. diversicolor $(\mathrm{mg} / \mathrm{kg})$ & 11,06 & 22,1 & 33,17 & 102,2 & 3900 \\
\hline Artiplexportulacoides $(\mathrm{mg} / \mathrm{kg})$ & 2,81 & 3 & 5,63 & 98,44 & 200 \\
\hline $\begin{array}{l}\text { Sarcocornia fructicosa } \\
\text { (mg/kg) }\end{array}$ & 12,7 & 60,5 & 35,05 & 22,3 & 300 \\
\hline Sediment $(\mathrm{mg} / \mathrm{kg})$ & 84,3 & 16,8 & 146,12 & 59,01 & 0 \\
\hline Water of the estuary (mg/l) & $<0,04$ & 0,02 & 0,715 & 0,01 & 800 \\
\hline
\end{tabular}

\section{CONCLUSION}

The spatial distribution of the demographic structure of M. galloprovincialis fluctuates widely from one area to another. It seems that it depends mainly on the physical and chemical factors, edaphic and hydrological coastline are: the nature of the substance, the tidal phenomenon, the availability of food and behavior of species. Different regression lines show that there is good correlation between the total length to the width of the shell, with significant correlation coefficients. This result demonstrates the use of this species as a bio indicator for monitoring the water quality of coastal Rabat -Sale.

Analysis of water, sediment, vegetation and macrofauna in the Bouregreg Estuary reveals that the entire compartment of this ecosystem is heavily contaminated by heavy metals $(\mathrm{Cr}, \mathrm{Cu}, \mathrm{Zn}, \mathrm{Pb}$ and $\mathrm{Fe})$. Similarly, we observe that there is accumulation and bioaccumulation from the water to the sediment and the biological part (benthic plants and animals). Concentrations that remain low in water are found in remarkable quantities in sediments and flora and fauna.

All the results of the analyzes carried out showed us that the macrofauna studied (edible bivalve molluscs) is not in conformity with the standards and therefore unsuitable for human consumption. The levels of lead and chromium at Sarcocornia fructicosa are significantly higher than those found at Artiplex portulacoides, it seems that this one has a relatively strong intake of these two metals which could be associated with the shape of its leaves Which promote storage. Plants have a very extensive root system that they use to extract water and minerals from the soil for their growth. During this extraction, they also absorb other compounds dissolved in 
the aqueous phase (heavy metals) and consequently the depollution of their biotope.

The ability of these two species to tolerate and accumulate these metals will open up a new avenue of research on the treatment of these areas (phytoremediation). In addition the accumulation of these metals in the macrofauna will play an important role as biological indicators of metal pollution

\section{REFERENCES}

[1] Basraoui Y, Zegmout M, El addouli j, Demnati S, Chahlaoui A et Chafi A 2010. SCIENCE 06(3) (2010) 64 $-74$

[2] Cheggour M., Texier H., Moguedet G. \&Elkaîm B. 1990. Hydrobiologia, 207, 209-219.

[3]Cheggour M., 1999.Thèse de Doct. Etat, Université Cadi Ayyad, Marrakech,315 pp.

[4] Cherkaoui E., Bayed A. et Hily C. 2003. Bio. Mar. (2003) 44 :339-352.

[5]Cherkaoui E., 2006. Thèse Doctorat, Université Mohammed V, Rabat. 305p.

[6]Cherkaoui E., Nounah A. and Khamar M. 2013.3. Journal of Environmental Science and Engineering B 2 (2013) 432-435

[7]Ciéslinski G. Vanrees J., Huang P.M. Kozak L.M. Rostad H.P. w. et Knott d. R. 1996. Plant and soil (182) pp: $115-124$.

[8] Clemente R., J. Walker David J., Bernal Pilar M.2005. The effect of soil amendments.Environmental Pollution 138 (2005) 46-58.

[9]-Djouai 2005. Journée d'études sur : « eau : vecteur du développement humain »1 Octobre 2005 pp.9

[10]Ebbs S.D., Last M.m., Bradyd j., Cornich J., Gordon R. And Kochian L.V. 1997. J. Environm. Qual. (26) pp : 1424-1430.

[11]El Morhit M., Fekhaoui M., Serghini A., El blidi S., El abidi A., Bennaakam R., Yahyaoui A. \& Jbilou M. 2008. Bulletin de l'Institut Scientifique, Rabat, section Sciences de la Terre, 2008, $\mathrm{n}^{\circ} 30,39-47$.

[12] Fellah A. 2009. Thèse Doctorat, Université AbouBekrBelkaid, Tlemcen.169p.

[13] Förstner U et Wittman GTW, 1981.).SpringerVerlag :Berlin; 486.

[14]Fournier j. , Bonnot-Courtois, paris R. Voldoire O. \& Levot M. 2012 : analyses granulométriques, principes et méthodes CNRST, Dinard, 99p.

[15] Gillert P. 1987. cahier de biologie Marine, 28 : 339350

[16] Hinsinger P. 2000. Topical Days on phytoanagement of contaminated Environments, Mol, Belgium, may 15 16.

[17] Kassaoui H., Lebkiri M., Lebkiri A., Rifi E., Badoc A. \& Douira A. 2009. Bull. Soc. Pharm. Bordeaux, 2009, $148,77-92$.

[18]Kaimoussi A., mouzdahi A., Bakkas S.\& Chafik A. 1998. Bulletin de 1'Institut Scientifique, Rabat, 19971998, n²1, pp. 95-102.

[19] Khamar M., Bouya D. \&Ronneau C. 1999. Africancrops science conferenceproceedings, Vol. 4.pp 263-267.
[20] Khamar M., Cherkaoui E. \&Nounah A. 201. Journées Internationales Oiseaux d'Eau et Zones Humides Faculté des Sciences Ben M'sik Casablanca 23-25 février 2012.

[21]Kourradi R., 2007. Thèse Doctorat ès Sciences, Université Mohamed V - Agdal Faculté des Sciences, Rabat, Maroc

[22] Lemine M. 1993. Thèse docorat 3 ème cycle, ENS, takaddoumrabat $337 \mathrm{p}$.

[23] Leval K.T. and Haselwandter K. 1997. Mycorrhizol (7), $\mathrm{pp}: 139-153$.

[24]Losi M. E., Amrhein C. and Frankenberg W. 1994..J. Environ. Qual. 23, pp: 1141-1150.

[25] Mengel K. et Kirkby E.A. 1987. Principles of plant nutrition. 4th edition $686 \mathrm{p}$.

[26] Sbaa M., Chergui H., Melhaoui M. MELHAOUI \&Bouali A. 2001.Actes Inst. Agron. Vet. (Maroc) 2001, Vol. 21 (1), 45-52.

[27] Smolders 2000 Topical Days on phytoanagement of contaminated Environments, Mol, Belgium, may 15 -16.

[28] Wang W., Vinocur B., Shoseyov O., Altman A. 2004. TRENDS in Plant Science 9 : 244-252.

[29]WHO, 1982. World Health Organization, Geneva, ISBN: 978-92-4-120940-3, pp: 106. 